\title{
Open Journal of Gastroenterology and Hepatology
}

(ISSN:2637-4986)

\section{Epidemiology and Risk Factors for Hepatitis C Infection in Malaysia:}

\section{A Narrative Review}

\section{Mohd Azri Mohd Suan ${ }^{1,2}$, Salmiah Md Said ${ }^{1 *}$, Ahmad Zaid Fattah Azman ${ }^{1}$, Muhammad Radzi Abu Hassan ${ }^{2,3}$ \\ ${ }^{1}$ Department of Community Medicine, Faculty of Medicine and Health Sciences, Universiti Putra Malaysia, 43400 Serdang, Selangor, Malaysia. ${ }^{2}$ Clinical Research Centre, Hospital Sultanah Bahiyah, KM 6, Jalan Langgar, 05460 Alor Setar, Kedah, Malaysia. ${ }^{3}$ Department of Medicine, Hospital Sultanah Bahiyah, KM 6, Jalan Langgar, 05460 Alor Setar, Kedah, Malaysia.}

\section{ABSTRACT}

Hepatitis $C$ infection is a growing public health issue in Malaysia. A large number of people living with hepatitis $C$ virus (HCV) are unaware of the infection. The treatment complexity warrants Keywords: epidemiology, hepatitis $\mathrm{C}$, infection, Malaysia, risk factor a comprehensive understanding of this infectious disease to support planning for strategies to reduce the burden of disease associated with hepatitis $\mathrm{C}$. This study aimed to summarise the epidemiology and risk factors attributable to hepatitis $C$ acquisition in Malaysia based on local published articles. Published articles related to epidemiology and risk factors for hepatitis C infection in Malaysia between 2005 and 2017 were searched through several online databases. Related information from the Ministry of Health official website was also compiled. An increasing trend in the incidence and mortality rate of hepatitis C infection is noted over the last decades. In 2009, the national prevalence of people infected with HCV was approximately $2.5 \%$, with the prevalence rate varying according to different high-risk groups. The most common genotypes reported are genotypes 3 and 1 . Frequently reported risk factor for HCV acquisition is injection drug use. Other identified risk factors are being a blood product recipient, haemodialysis patient or participant in high-

*Correspondence to Author:

Salmiah Md Said

Department of Community Medicine , Faculty of Medicine and Health Sciences, Universiti Putra Malaysia, 43400 Serdang, Selangor, Malaysia Tel: +60389472300

How to cite this article:

Mohd Azri Mohd Suan, Salmiah Md Said, Ahmad Zaid Fattah Azman, Muhammad Radzi Abu Hassan. Epidemiology and Risk Factors for Hepatitis C Infection in Malaysia: A Narrative Review. Open Journal of Gastroenterology and Hepatology, $2021 ; 4: 53$.

risk sexual activity. Nevertheless, a considerable number of patients had no known risk factors. The prevalence and burden of HCV-related disease are substantial and can be attributed to many factors. High-quality design studies are needed to provide stronger evidence of the risk factors for hepatitis $C$ infection in local populations for future public health planning. 


\section{Introduction}

Hepatitis $C$ is a blood-borne disease that results from hepatitis $\mathrm{C}$ virus $(\mathrm{HCV})$ infection. The virus was discovered in the serum of a patient with non-A, non-B hepatitis in 1989. ${ }^{[1]} \mathrm{HCV}$ is an RNA virus that belongs to the family Flaviviridae. ${ }^{[2]}$ Genetic analysis of the full-length or partial genome sequences of HCV strains isolated in various regions of the world resulted in the identification of the HCV genotypes. Six major genotypes (numbered 1-6) are commonly found worldwide, ${ }^{[3]}$ although several studies indicated that the number may increase to $11 .{ }^{[4]}$ At 20-30 years after initial HCV infection, persistent hepatic inflammation leads to the development of cirrhosis in $10 \%-20 \%$ of patients. ${ }^{[5]}$ Upon diagnosis of cirrhosis, patients have between $1 \%$ $5 \%$ annual risk of developing hepatocellular carcinoma, a 3\%-6\% annual risk of hepatic decompensation and ultimately death. $[5,6]$

Challenging issues in the HCV infection control and treatment programme have emerged due to the difficulty in diagnosing infected patients at an early stage, along with unavailable and costly drugs in several countries. The World Health Organization (WHO) estimated that in 2015, 71 million people live with chronic $\mathrm{HCV}$ infection. [7] The global incidence rate is 23.7 per 100,000 population, with the WHO Eastern Mediterranean and European regions showing the highest incidence rate of 62.5 and 61.8 per 100,000 population, respectively. ${ }^{[7]}$ Moreover, the global mortality rate caused by viral hepatitis is 18.3 deaths per 100,000 population. Although the Western Pacific region presents the lowest incidence of HCV infection (6.0 per 100,000 population), this region reported the highest mortality rate due to viral hepatitis (24.1 deaths per 100,000 which accounts for 446,000 deaths). ${ }^{[7]}$ In addition to HCV prevalence studies, measurement of the HCV genotype frequency has become a new tool for monitoring epidemiological trends. With regard to the global HCV genotype distribution, genotypes $1,3,2,4,6$ and 5 account for $46 \%, 22 \%, 13 \%, 13 \%, 2 \%$ and $1 \%$ of all $\mathrm{HCV}$ infections among adults, respectively. ${ }^{\left[{ }^{[8]}\right.}$
Malaysia is also confronted with the burden of HCV infection. An estimated 397,515 HCV-infected persons were living in Malaysia in 2010. ${ }^{[9]}$ According to the Ministry of Health (MOH), Malaysia, the incidence and mortality rates of hepatitis $C$ have increased over the last decades. ${ }^{[10-}$ 12] The large number of people who are unaware that they are carrying HCV and the complexity of treatment warrant more comprehensive understanding about this infectious disease to support planning strategies to reduce the burden of morbidity associated with hepatitis $C$. Thus, the aim of this review is to summarise the epidemiology and risk factors attributable to hepatitis $\mathrm{C}$ infection in Malaysia.

\section{Methods}

\section{Search Strategy}

A literature search for articles related to epidemiology and risk factors for hepatitis $C$ infection in Malaysia between 2005 and 2017 was conducted through several online databases (e.g. Cumulative Index to Nursing and Allied Health Literature [CINAHL], Cochrane database, PubMed, Medical Literature Analysis and Retrieval System Online [MEDLINE], Science Direct, and Scopus database). The search terms included: (Malaysia) and (hepatitis C OR HCV) and (epidemiology OR incidence OR prevalence OR mortality) and (risk behaviour OR risk factor). Additional studies were identified through a manual search of references found in the publications. Only articles and abstracts published in English were included in this review. The authors also searched for official health reports related to hepatitis $\mathrm{C}$ infection from the $\mathrm{MOH}$ Malaysia website. HCV genotype and HCV seroconversion proportion or prevalence were recorded if available. Through the literature search, a total of 25 articles related to epidemiology and risk factors for HCV infection in Malaysia were included in this review. Data on the incidence and mortality of hepatitis $C$ infection were mainly obtained from the $\mathrm{MOH}$ Malaysia official website.

\section{Ethical Approval}

This review was conducted as part of ongoing research on risk factors for hepatitis $C$ infection 
among adult patients in Malaysia (NMRR-173322-38795).

\section{Results}

Incidence and mortality rates of hepatitis $C$ infection in Malaysia

According to the Malaysia Health Indicator Report and Health Facts, more than 18,000 new cases of hepatitis $C$ infection were reported from 2005 to $2017 . .^{10-12}$ Over 460 deaths were attributed to hepatitis $C$ infection in Malaysia for the same 13-year period. The national incidence rate of hepatitis $C$ was 3.81 per 100,000 population in 2005, and this gradually increased over the years to 5.2 per 100,000 population in 2007 (Figure 1). The incidence rate was low between 2008 and 2010. Since 2011, an upward trend has been observed in the incidence rate, and the highest rate of 9.54 per 100,000 population was reported in 2017. ${ }^{[10-12]}$ Figure 2 shows the mortality rate for hepatitis $\mathrm{C}$ infection in Malaysia. In 2005, the mortality rate was 0.08 per 100,000 population. Subsequently, the rate shows a fluctuating trend, and the highest mortality rate was recorded in 2016 at 0.3 per 100,000 population. [10-12]

Figure 1. Incidence rates of hepatitis C infection in Malaysia in 2005-2017
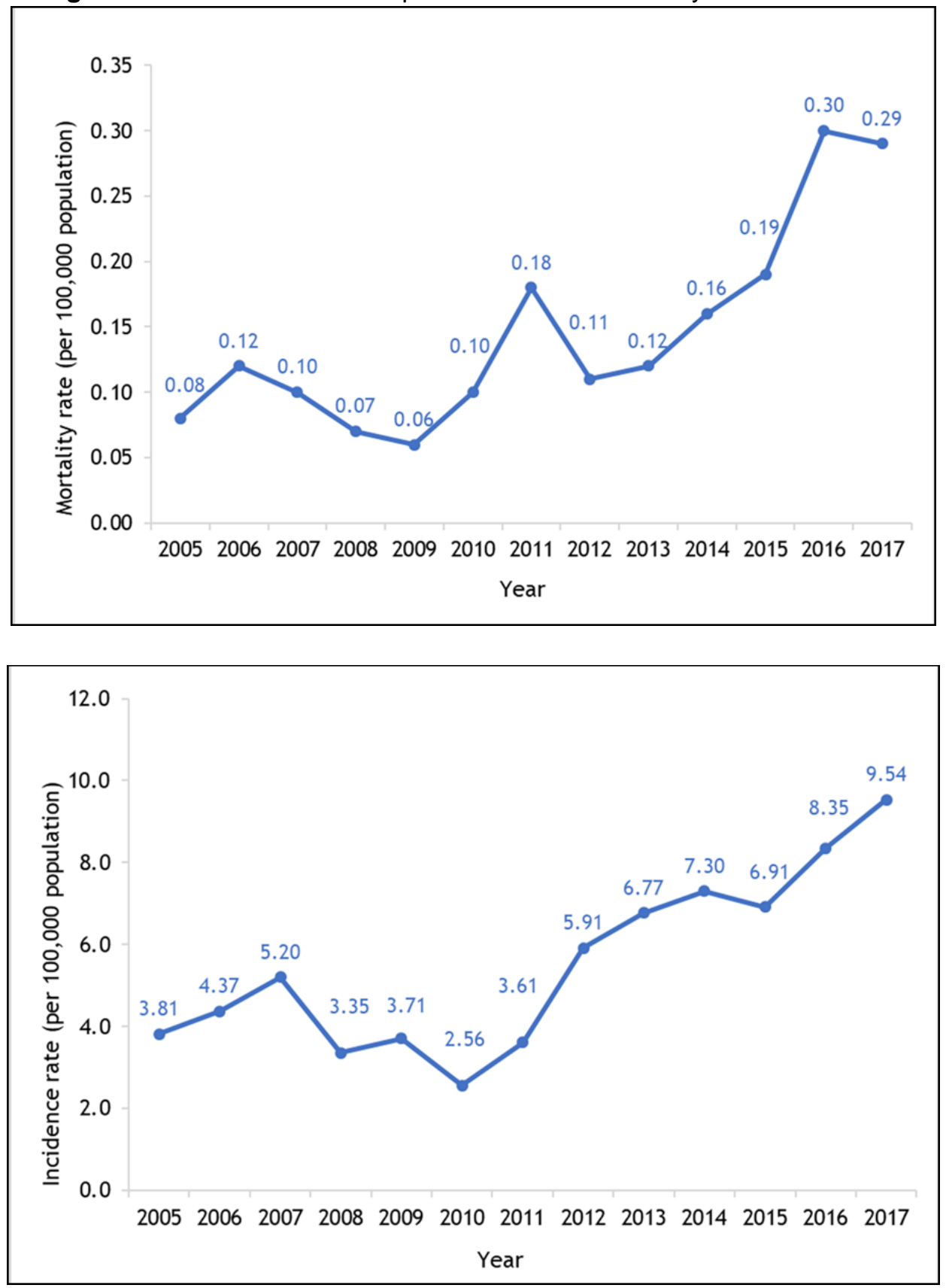

Figure 2. Mortality rates of hepatitis C infection in Malaysia in 2005-2017 


\section{Prevalence and disease burden}

Using a multi-parameter evidence synthesis method, McDonald et al. ${ }^{[13]}$ estimated approximately 453,700 hepatitis C-infected persons living in Malaysia in 2009; this number represents $2.5 \%$ of the population aged $15-64$ years. The estimated prevalence of HCV infection in males $(4.0 \%)$ is higher than in females $(1.0 \%)$. ${ }^{[13]}$ Males of Malay ethnicity had the highest prevalence rate as compared to other ethnic groups (Chinese and Indian). ${ }^{[13]}$ However, the HCV prevalence in Malaysia for 2010 was lower at $1.5 \%$ which represents 397,515 infected people. ${ }^{[9]}$ Furthermore, McDonald et al. ${ }^{\left[{ }^{[4]} \text { conducted a }\right.}$ study to estimate the current and future HCV-related disease burden up to the year 2039 using an age-structured multi-state Markov model. The study projected the disease burden for the year
2039 to be 94,900 disability-adjusted lifeyears/year. The numbers of individuals predicted to develop decompensated cirrhosis and hepatocellular carcinoma were projected to be 2,002 and 540 , respectively, in that year. The projected $\mathrm{HCV}$-related death rate was 63,900 deaths in 2039. ${ }^{[14]}$ The prevalence of HCV in Malaysia in various studies between 2009 and 2011 are summarised in figure 3 . In a more recent study by Chan et al., ${ }^{[15]}$ a disease progression model was used to estimate the future disease burden by the year 2030 in many countries including Malaysia. The study estimated the viraemic prevalence in 2015 was $1.3 \%$ and projected $343,000 \mathrm{HCV}$ infection cases in 2030, an $11 \%$ reduction from 2015. However, liver-related death and hepatocellular carcinoma are both projected to rise in 2030. ${ }^{[15]}$

Figure 3. Prevalence rates of hepatitis $C$ infection in Malaysia based on various studies between 2009 and 2011

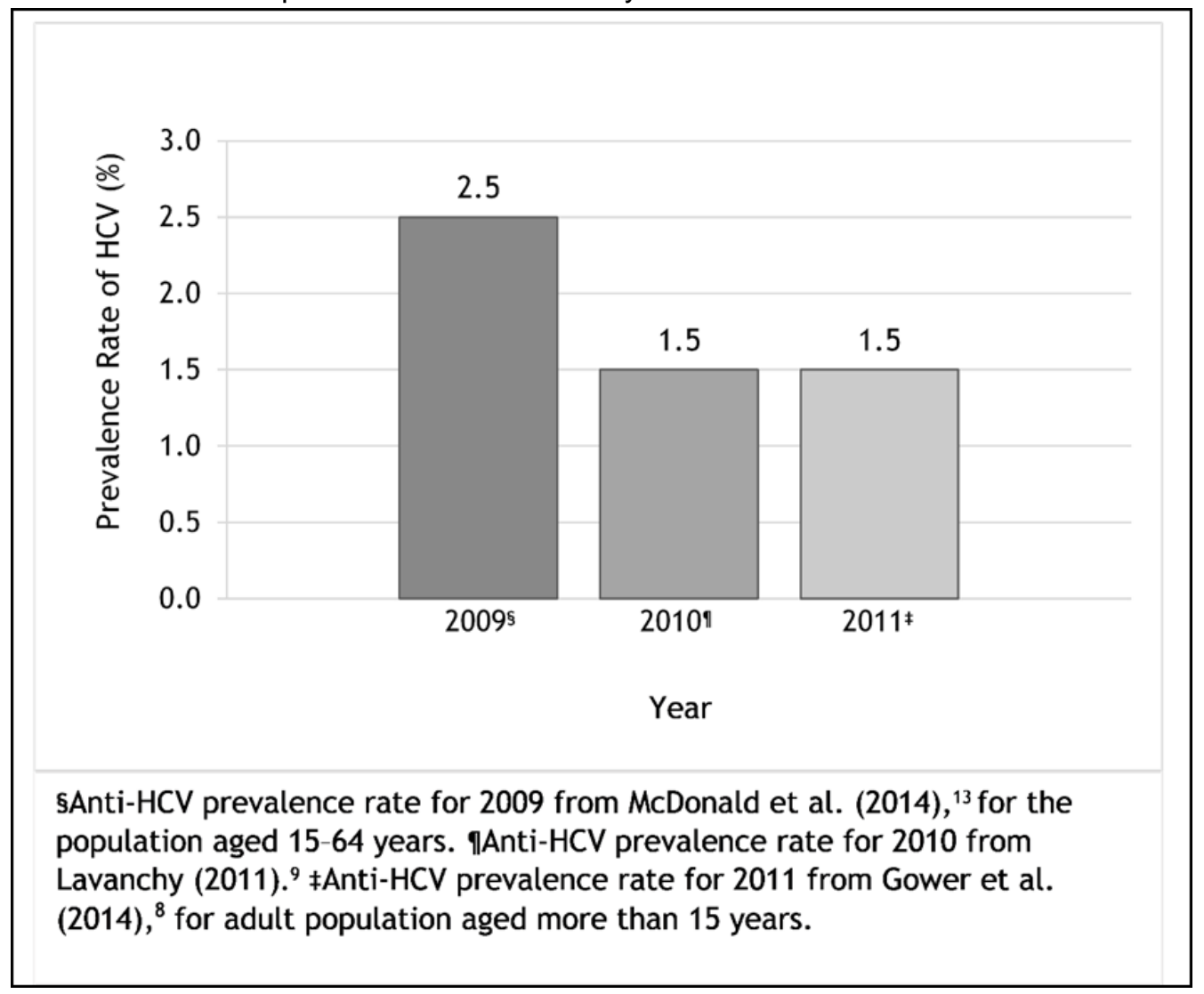

Published local data focusing on specific highrisk populations show varying prevalence rates (Table 1). For instance, according to the Malaysian Dialysis and Transplant Registry report, the prevalence of anti-HCV positivity among haemodialysis patients was $14 \%$ (total patients $=8956)$ in 2005 and decreased to $4.0 \%$ (total patients = 31665) in 2014. ${ }^{[16]}$ In another small study involving 35 patients undergoing haemodialysis, $20.0 \%$ of the patients tested positive for HCV. ${ }^{[17]}$ The prevalence is also high among injection drug users. Vicknasingam et al. ${ }^{[18]}$ found that the 
HCV prevalence rate in their cohort of injection drug users was $67.1 \%$. Results from a clinical trial involving 177 heroin-dependent users in Muar, Johor concluded that $89.9 \%$ of them are infected with HCV. ${ }^{[19]}$ Choo et al. ${ }^{[20]}$ conducted a prevalence study in a fisherman population and found $49.6 \%$ (199/401) were positive for $\mathrm{HCV}$ infection. The introduction of HCV screening for donor blood has made the blood transfusion safer to the recipient. Haslina et al. ${ }^{[21]}$ reported that the overall seroprevalence of antiHCV positive status is $0.45 \%$ of the 6,495 blood donors in NorthEastern Malaysia. Another study of blood donors at the National Blood Centre revealed that the seroprevalence for HCV was hovering between $4.8 \%$ and $8.37 \%$ per 100,000 person years for 2004 till 2008. ${ }^{[22]}$ Results from four studies were also reviewed in terms of age and gender distributions of the HCV-infected persons. The estimated prevalence in males is higher than in females (4\% vs. $1 \%$ ), ${ }^{[13]}$ indicating a larger number of males are involved in highrisk activity associated with $\mathrm{HCV}$ infection. Other studies also confirmed the male predominance among local patients with HCV. ${ }^{[23,24]}$ The prevalence shows its peak at $35-49$ years of age in both genders. ${ }^{[15,23,25]}$

Table 1. Prevalence of HCV in selected groups in Malaysia

\begin{tabular}{|c|c|c|c|}
\hline $\begin{array}{l}\text { Authors, year of pub- } \\
\text { lication }\end{array}$ & Study design & HCV prevalence & Setting \\
\hline $\begin{array}{l}\text { Chawarski et al., } \\
2006^{19}\end{array}$ & Clinical trial & $89.9 \%$ & $\begin{array}{l}159 \text { heroin-dependent users in } \\
\text { Muar, Johor. }\end{array}$ \\
\hline $\begin{array}{l}\text { Vicknasingam et al., } \\
2009^{18}\end{array}$ & Cross-sectional & $67.1 \%$ & $\begin{array}{l}552 \text { active street drug users in five } \\
\text { cities across Peninsular Malaysia. }\end{array}$ \\
\hline Jaafar et al., $2011^{17}$ & Cross-sectional & $20.0 \%$ & $\begin{array}{l}35 \text { patients with haemodialysis treat- } \\
\text { ment at UKMMC. }\end{array}$ \\
\hline Haslina et al., $2012^{21}$ & Cross-sectional & $0.9 \%$ & 6495 blood donors at HUSM. \\
\hline $\begin{array}{l}\text { Mohamed et al., } \\
2013^{28}\end{array}$ & Cross-sectional & $71.0 \%$ & 89 patients from UKMMC. \\
\hline Choo et al., $2015^{20}$ & Cross-sectional & $49.6 \%$ & 401 fishermen in Kuantan, Pahang. \\
\hline Claire et al., $2015^{16}$ & Registry report & $4.0 \%$ & $\begin{array}{l}31,665 \text { patients undergoing haemo- } \\
\text { dialysis in } 2014 \text {. }\end{array}$ \\
\hline Maaroufi et al., $2017^{25}$ & Cross-sectional & $1.9 \%$ & $\begin{array}{l}523 \text { patients infected with HCV. } \\
\text { Data from Selayang Hospital. }\end{array}$ \\
\hline
\end{tabular}

Notes: HCV, hepatitis C virus; HUSM, Hospital Universiti Sains Malaysia; UKMMC, Universiti Kebangsaan Malaysia Medical Centre.

Table 2. HCV genotype distribution in Malaysia

\begin{tabular}{|c|c|c|c|c|c|c|c|}
\hline \multirow{2}{*}{$\begin{array}{l}\text { Author, year of } \\
\text { publication }\end{array}$} & \multirow[t]{2}{*}{ Study design } & \multirow[t]{2}{*}{ Setting } & \multicolumn{5}{|c|}{$\begin{array}{l}\text { HCV genotype distribution (in per- } \\
\text { centage) }\end{array}$} \\
\hline & & & 1 & 2 & 3 & 4 & 6 \\
\hline $\begin{array}{l}\text { Hamzah et al., } \\
2010^{28}\end{array}$ & $\begin{array}{l}\text { Cross-sec- } \\
\text { tional }\end{array}$ & $\begin{array}{l}39 \text { haemodialysis pa- } \\
\text { tients in state of } \mathrm{Pa} \text { - } \\
\text { hang. }\end{array}$ & 23.1 & - & 66.6 & 2.6 & 5.1 \\
\hline $\begin{array}{l}\text { Jaafar et al., } \\
2011^{17}\end{array}$ & $\begin{array}{l}\text { Cross-sec- } \\
\text { tional }\end{array}$ & $\begin{array}{l}35 \text { patients with hae- } \\
\text { modialysis at UKMMC. }\end{array}$ & 57.1 & - & - & - & - \\
\hline $\begin{array}{l}\text { Mohamed et al., } \\
2013^{27}\end{array}$ & $\begin{array}{l}\text { Cross-sec- } \\
\text { tional }\end{array}$ & $\begin{array}{l}89 \text { patients from } \\
\text { UKMMC. }\end{array}$ & 27.0 & - & 73.0 & - & - \\
\hline
\end{tabular}

OJGH: https://escipub.com/open-journal-of-gastroenterology-and-hepatology/ 


\begin{tabular}{|c|c|c|c|c|c|c|}
\hline Ho et al., $2015^{26}$ & $\begin{array}{l}\text { Cross-sec- } \\
\text { tional }\end{array}$ & $\begin{array}{l}396 \text { patients infected } \\
\text { with HCV from UMMC. }\end{array}$ & 35.9 & 1.8 & 61.9 & \\
\hline Tan et al., $2015^{30}$ & $\begin{array}{l}\text { Cross-sec- } \\
\text { tional }\end{array}$ & $\begin{array}{l}45 \text { patients with HIV- } \\
\text { HCV coinfection } \\
\text { treated at Sungai Buloh } \\
\text { Hospital. }\end{array}$ & 26.7 & - & 73.3 & - \\
\hline $\begin{array}{l}\text { Maaroufi et al., } \\
2017^{25}\end{array}$ & $\begin{array}{l}\text { Cross-sec- } \\
\text { tional }\end{array}$ & $\begin{array}{l}523 \text { patients infected } \\
\text { with HCV. Data from } \\
\text { Selayang Hospital. }\end{array}$ & 36.0 & 1.0 & 62.0 & 1.0 \\
\hline $\begin{array}{l}\text { Tan \& Adlin, } \\
2017^{24}\end{array}$ & $\begin{array}{l}\text { Cross-sec- } \\
\text { tional }\end{array}$ & $\begin{array}{l}269 \text { patients infected } \\
\text { with HCV at Selayang } \\
\text { Hospital. }\end{array}$ & 36.1 & 1.8 & 60.6 & 1.1 \\
\hline $\begin{array}{l}\text { Durier et al., } \\
2017^{29}\end{array}$ & $\begin{array}{l}\text { Cross-sec- } \\
\text { tional }\end{array}$ & $\begin{array}{l}24 \text { patients with HIV- } \\
\mathrm{HCV} \text { coinfection } \\
\text { treated at UMMC. }\end{array}$ & 41.7 & - & 54.2 & - \\
\hline $\begin{array}{l}\text { Siti Nurul Fazlin } \\
\text { et al., } 2017^{31}\end{array}$ & $\begin{array}{l}\text { Cross-sec- } \\
\text { tional }\end{array}$ & $\begin{array}{l}40 \text { HCV-positive pa- } \\
\text { tients attending Medi- } \\
\text { cal Outpatient Gastro- } \\
\text { enterology clinic, } \\
\text { HTAA. }\end{array}$ & 16.2 & - & 80.6 & - \\
\hline
\end{tabular}

Notes: HIV, human immunodeficiency virus; HCV, hepatitis C virus; HTAA, Hospital Tengku Ampuan Afzan; UKMMC, Universiti Kebangsaan Malaysia Medical Centre; UMMC, University Malaya Medical Centre.

\section{Genotype distribution}

Genotypes 3 and 1 are the most commonly reported in our multi-ethnic country. ${ }^{[17,24-31]}$ This finding is in accord with that of Gower et al. ${ }^{[8]}$ In this review study, Gower reported that higher percentages of genotypes 3 and 1 were found in Malaysia, accounts for $58.6 \%$ and $31.9 \%$, respectively. Other common genotypes found locally but in small proportion are genotypes 2, 4 and 6. HCV genotype distribution in selected groups in Malaysia is summarised in Table 2. Although uncommon, mixed genotype infections can occur when a patient with HCV infection presents with more than one genotype. Siti Nurul Fazlin et al. reported a single patient with mixed genotype (3a/1a) found in their study at a tertiary hospital in eastern peninsular Malaysia. ${ }^{[31]}$ In another local study involving 40 patients undergoing haemodialysis, five subjects $(12.5 \%)$ were reported with mixed genotype infections. ${ }^{\text {[32] }}$

Risk factors for Hepatitis $C$ acquisition in Malaysia

The risk factors attributable to $\mathrm{HCV}$ acquisition were identified in several at-risk groups in Malaysia such as injection drug users (IDU), blood product recipients, haemodialysis patients, and those involved in high-risk sexual behaviour. Injection drug use. Among upper-middle income countries, Malaysia has a large prevalence (67\%) of HCV infection among people who inject drugs. ${ }^{[33]}$ In a cross-sectional study comprising 713 patients infected with HCV in Kota Setar District in the state of Kedah, more than threequarters of the studied population were involved in injection drug use. ${ }^{[23]}$ Similarly, $28.9 \%$ of the 273 patients with HCV treated at a governmentfunded tertiary centre had previously used injection drugs. ${ }^{[4]}$ Ten of $31 \mathrm{HCV}$-positive patient $(32.3 \%)$ in tertiary hospital in Eastern peninsular Malaysia also reported to use injection drugs. ${ }^{[31]}$ A large proportion of hepatitis $C$ infection cases were also reported among injection drug users receiving methadone replacement therapy at three clinics in Penang state. ${ }^{[34]}$ Risk factors for contracting HCV infection among active street drug users in five cities across Peninsular Malaysia were also studied. ${ }^{18]}$ The study results indicate that injection drug users have higher probability of contracting HCV by 2.2 times compared with that of non-injection drug users. The same study also reported that people who inject drugs and share the injecting equipment relative to al-of-gastroenterology-and-hepatology/ 
those who do not inject, and those engaged in homosexual or bisexual behaviour relative to heterosexuals, carry 2.2- and 1.3-times higher risk of testing positive for $\mathrm{HCV}$, respectively. A study conducted among the fisherman population on the east coast of Malaysia found that a positive HCV test is significantly associated with injection drug use. [20]

Blood products recipients. Improved testing and screening for blood donors became available in mid-1992, but recipients of blood transfusions before that period are at risk for $\mathrm{HCV}$ infection. ${ }^{35}$ Tan and Adlin found that $28.2 \%$ of their patients who are HCV-positive reported history of blood or blood product transfusion before 1994, ${ }^{[24]}$ and $4.9 \%$ of patients with HCV in Kota Setar District reported similar exposure.$^{23}$ Analysis of national liver registry data from 2001 till 2010 revealed $31.6 \%$ of $460 \mathrm{HCV}$-infected patients had previous transfusion of blood products. ${ }^{[36]}$ In another study conducted among children with multitransfused thalassaemia, three new seroconversions for anti-HCV were detected at the study endpoint (median duration between start and endpoint was 49 months), indicating potential of acquiring $\mathrm{HCV}$ infection despite regular screening of donated blood. ${ }^{\left[{ }^{37]}\right.}$ Nevertheless, this study finding was limited by its small sample size and possible involvement of other modes of virus transmission among the blood recipients.

Haemodialysis patients. A study using data obtained from the national renal registry indicates that patients who received haemodialysis display higher prevalence of $\mathrm{HCV}$ than those who received peritoneal dialysis. ${ }^{[16,38]}$ Another crosssectional study at a university hospital suggested that the predisposing factors for hepatitis $\mathrm{C}$ infection among patients undergoing haemodialysis are as follows: duration of haemodialysis, history of dialysis at multiple centres and place of haemodialysis. ${ }^{[17]}$ In a tertiary hospital in eastern peninsular Malaysia, $9.7 \%$ of the HCV-positive patients had haemodialysis in the past. ${ }^{[31]}$ Furthermore, the same study also reported an outbreak of HCV infection at the centre involving three patients after one of them received haemodialysis at Mecca during Hajj season. Haemodialysis was also reported as one of the potential risk factors by $9.0 \%$ of the $460 \mathrm{HCV}$-infected patients registered with the Malaysian national liver registry. ${ }^{[37]}$

High-risk sexual activity. The growing number of people engaged in high-risk sexual behaviour, such as commercial sex workers and men who have sex with men, withstand and pose a threat for HCV infection. However, only two local studies reported on sexual behaviour among HCV infected people. Tan et al. found that $3.9 \%$ of patients infected with HCV reported sexual contact with an infected partner. ${ }^{[23]}$ Patients also self-reported having heterosexual $(6.2 \%)$ and homosexual behaviour (1.1\%) as a risk for acquiring HCV. [24]

Other risk factors. Other reported risk factors for $\mathrm{HCV}$ infection in Malaysia are tattoo, body piercing, needle stick injury and vertical transmission (birth to an infected mother). ${ }^{[23,24,37]}$ Almost 7.5\% of $\mathrm{HCV}$ patients from the national liver registry in 2006 reported having a tattoo as a possible factor for hepatitis $\mathrm{C}$ infection. ${ }^{[37]}$ However, other reported risk factors for acquiring $\mathrm{HCV}$ infection constituted a small percentage (1\% or less). ${ }^{[23,24]} \mathrm{A}$ remarkable concern is the presence of patients with HCV who denied any exposure to the commonly known risk factors. Four studies reported that between $8.0 \%$ and $42.0 \%$ of their studied population had no known risk factors, $[23,24,31,37]$ thereby suggesting that unidentified modes of transmission still exist in the local population.

\section{Discussion}

The increasing incidence trend of HCV in Malaysia can be attributed to many factors, mainly the growing high-risk population such as injection drug users, haemodialysis patients and people with high-risk sexual activity. Given that improved testing and screening methods for blood donors have become increasingly available, blood transfusion is becoming safer than before, and the main cohort of newly infected patients is people who inject drugs. ${ }^{[39]}$ The most significant event attributable to the increasing HCV incidence trend is the introduction of harm reduction strategies which consist of methadone al-of-gastroenterology-and-hepatology/ 
maintenance therapy (MMT) and a needle/syringe exchange programme in Malaysia. [39,40]

Since started in 2005, this strategy has expanded rapidly nationwide over the years. By mid-2014, approximately 65,000 drug users had accessed MMT service from public and private health facilities. [40] Drug users who received MMT service were required to be screened for HCV. Eventually, a large number of HCV-infected drug addicts were captured into the surveillance system and explains for the increasing trend of HCV. Nevertheless, an HCV education session should be added to the harm reduction services to improve HCV knowledge and awareness on risky behaviour among drug users. [41] Other high-risk groups that need attention from the public health authorities when planning for disease prevention are commercial sex workers, men who have sex with men, and patients who require haemodialysis treatment.

Most of the published works in Malaysia have used a cross-sectional study design (Table 1 and 2). Therefore, they provide insufficient evidence regarding the risk factors for hepatitis $C$ infection in Malaysia. A future study using a retrospective/prospective case-control design is proposed to help establish evidence of whether an exposure is associated with an outcome/disease. ${ }^{[42] ~ I n ~ a d d i t i o n, ~ s e v e r a l ~ s u p p o s e d l y ~ h i g h-~}$ risk groups are unexplored in terms of their association with HCV infection. For instance, being a healthcare worker is a known occupational risk for HCV transmission, ${ }^{[9]}$ but this variable remains uninvestigated in the local population. Several other traditional/cultural activities (male circumcision by traditional practitioner, home birth by traditional midwife) that are commonly practiced in the past, and high-risk activities that are becoming popular (cupping therapy, acupuncture treatment) in the local population, can pose risks for HCV infection but are not mentioned in any published article. These practices could be contributing factors to the cohort of HCV-positive patients that were grouped as having no known risk factor in four previous studies. $[23,24,31,37]$ Further study is needed to determine any other unidentified route of HCV transmission.

In summary, numerous studies had been conducted to establish reliable epidemiological data on HCV infection in Malaysia. ${ }^{[8,9,13,15]}$ Given its chronic effect on the liver, together with the aging population, the prevalence and burden of HCV-related disease are substantial and expected to increase over the coming years. A high-quality, well-designed study is also required to examine other unknown risk factors for hepatitis $C$ infection in the local population for future public health planning. Identifying these unknown transmission routes is vital to facilitate the design of effective preventative programmes among relevant stakeholders.

\section{Conflict of Interest}

All authors declare that they have no conflict of interest to disclose. This work received no specific grant from any funding agency in the public, commercial, or not-for-profit sectors

\section{Acknowledgement}

The authors would like to thank the Director General of Health Malaysia, for his permission to publish this review article.

\section{REFERENCES}

[1] Choo QL, Kuo G, Weiner AJ, et al. Isolation of a cDNA clone derived from a blood-borne non-A, non-B viral hepatitis genome. Science. 1989; 244:359-62.

[2] Lauer GM, Walker BD. Hepatitis C virus infection. N Engl J Med. 2001; 345:41-52.

[3] Zein NN. Clinical Significance of Hepatitis C Virus Genotypes. Clin Microbiol Rev. 2000; 13:223-35.

[4] Pozzetto B, Memmi M, Garraud O, Roblin X, Berthelot P. Health care-associated hepatitis C virus infection. World J Gastroenterol. 2014; 20:17265-78.

[5] Westbrook RH, Dusheiko G. Natural history of hepatitis C. J Hepatol. 2014; 61:S58-68.

[6] Modi AA, Liang TJ. Hepatitis C: a clinical review. Oral Dis. 2008; 14:10-4.

[7] World Health Organization. Global Hepatitis Report 2017. Available at: http://www.who.int/hepatitis/publications/global-hepatitis-report2017/en/. Accessed May 17, 2017.

[8] Gower E, Estes C, Blach S, Razavi-Shearer K, Razavi H. Global epidemiology and genotype distribution of the hepatitis $C$ virus infection. $J$ Hepatol. 2014; 61(1 Suppl):S45-57. 
[9] Lavanchy D. Evolving epidemiology of hepatis $C$ virus. Clin Microbiol Infect. 2011; 17:107-15.

[10] Ministry of Health Malaysia. Health Indicators 2011 - 2017. Available at:

http://vlib.moh.gov.my/cms/con-

tent.jsp?id=com.tms.cms.section. Section_3296f5dc-a0188549-72493700-64325650.

Accessed December 22, 2017.

[11] Ministry of Health Malaysia. Health Indicators 2005 - 2010. Available at:

http://vlib.moh.gov.my/cms/con-

tent.jsp?id=com.tms.cms. section.

Section_3296b2e7-a0188549-72493700-

9226a980. Accessed December 22, 2017.

[12] Ministry of Health Malaysia. Health Facts 2018.

Available at:

http://www.moh.gov.my/resources/index/Pen-

erbitan/Penerbitan\%20Utama/Fakta\%20

kesihatan/KKM_HEALTH_FACTS_2018.pdf.

Accessed November 17, 2017.

[13] McDonald SA, Mohamed R, Dahlui M, Naning H, Kamarulzaman A. Bridging the data gaps in the epidemiology of hepatitis $\mathrm{C}$ virus infection in Malaysia using multi-parameter evidence synthesis. BMC Infect Dis. 2014; 14:564.

[14] McDonald SA, Dahlui M, Mohamed R, et al. Projections of the current and future disease burden of hepatitis $C$ virus infection in Malaysia. PLoS One. 2015; 10:e0128091.

[15] Chan HLY, Chen CJ, Omede O, et al. The present and future disease burden of hepatitis $C$ virus infections with today's treatment paradigm: Volume 4. J Viral Hepat. 2017; 24:25-43.

[16] Clare THH, Chow YW, Lawrence HWS, Loh CL, Teo SM. Hepatitis on dialysis. In: 22nd Report of The Malaysian Dialysis \& Transplant Registry 2014. Available at: https://msn.org.my/nrr/mdtr2014.jsp. Accessed May 25, 2017.

[17] Jaafar R, Isahak I, Wong K, et al. Prevalence and predisposing factors for hepatitis $C$ virus in haemodialysis unit at the Universiti Kebangsaan, Malaysia Medical Centre. BMC Proc. 2011; 5:P210.

[18] Vicknasingam B, Narayanan S, Navaratnam V. Prevalence rates and risk factors for hepatitis $C$ among drug users not in treatment in Malaysia. Drug Alcohol Rev. 2009; 28:447-54.

[19] Chawarski MC, Mazlan M, Schottenfeld RS. Heroin dependence and HIV infection in Malaysia. Drug Alcohol Dependence. 2006; 82 (Suppl 1):S39-42.

[20] Choo MKK, El-Bassel N, Adam PCG, et al. Prevalence and correlates of HIV and hepatitis $\mathrm{c}$ virus infections and risk behaviors among Malaysian fishermen. PloS One. 2015; 10:e0118422.

[21] Haslina MNN, Khairiah Y, Zainy DZ, et al. Seroprevalence of hepatitis $C$ virus infection among blood donors in a teaching hospital in northeastern Malaysia. Southeast Asian J Trop Med Public Health. 2012; 43:668-73.

[22] Nafishah A, Asiah MN, Syimah ATN, et al. Rate of seroconversion in repeat blood donors at the national blood centre, Kuala Lumpur. Indian J Hematol Blood Transfus. 2014; 30:105-10.

[23] Tan WL, Yihui G, Abu Hassan MR. Demographic characteristics and intravenous drug use among hepatitis $C$ patients in the Kota Setar District, Kedah, Malaysia. Epidemiology Health. 2015; 37:e2015032.

[24] Tan SS, Adlin Nadia Z. The clinical features and treatment outcome of chronic hepatitis $C$ with pegylated interferon and ribavirin in routine care. Med J Malaysia. 2017; 72:165-74.

[25] Maaroufi A, Vince A, Himatt SM, et al. Historical epidemiology of hepatitis $C$ virus in select countries, vol. 4. J Viral Hepat. 2017; 24 (Suppl 2):824.

[26] Ho SH, Ng KP, Kaur H, Goh KL. Genotype 3 is the predominant hepatitis $C$ genotype in a multiethnic Asian population in Malaysia. Hepatobiliary Pancreatic Disease Int. 2015; 14:281-6.

[27] Mohamed NA, Zainol Rashid Z, Wong KK, Abdullah SA, Rahman MM. Hepatitis $C$ genotype and associated risks factors of patients at the University Kebangsaan Malaysia Medical Centre. Pak J Med Sci. 2013; 29:1142-6.

[28] Hamzah H, Hasmoni M, Saad M, et al. Hepatitis $\mathrm{C}$ genotyping in haemodialysis patients and the development of genotyping method based on TaqMan probe real-time PCR. Hepatol Int. 2010; 4:179.

[29] Durier N, Yunihastuti E, Ruxrungtham K, et al. Chronic hepatitis $C$ infection and liver disease in HIV-coinfected patients in Asia. J Viral Hepat. 2017; 24:187-96.

[30] Tan SS, Leong CL, Lee CKC. Treating hepatitis $\mathrm{C}$ in HIV/HCV co-infected patients in Malaysia the outcomes and challenges. Med $\mathrm{J}$ Malaysia. 2015; 70:281-7.

[31] Siti Nurul Fazlin AR, Hairul Aini H, Hadzri HM. Study of Hepatitis $C$ virus infection in tertiary hospital: genotyping, risk factors and comorbidities. International Medical Journal Malaysia. 2017; 16:11-20.

[32] Hairul Aini H, Mustafa MIA, Seman MR, Nasuruddin BA. Mixed-genotypes infections with hepatitis $C$ virus in haemodialysis subjects. Med J Malaysia. 2012; 67:199-203. 
[33] O'Keefe D, Stoové M, Doyle J, Dietze P, Hellard $M$. Injecting drug use in low and middle-income countries: opportunities to improve care and prevent harm. J Viral Hepat. 2017; 24:714-24.

[34] Gillani SW, Sulaiman SAS. Chronic infections and management setting in drug addicts of MMT program in Pinang, Malaysia. Int $\mathrm{J}$ Collab Res Intern Med Public Health. 2009; 1:48-54.

[35] World Health Organization. Hepatitis C Fact Sheet 2017. Available at: http://www.who.int/mediacentre/factsheets/fs164/en/. Accessed April 28, 2017.

[36] Tan S, Menon J, Radzi M, et al. The demography and risk profiles for chronic hepatitis $B$ and $C$ from the Malaysian liver registry. Med $\mathrm{J}$ Malaysia. 2011; 66:31.

[37] Lee WS, Teh CM, Chan LL. Risks of seroconversion of hepatitis $B$, hepatitis $C$ and human immunodeficiency viruses in children with multitransfused thalassaemia major. J Paediatr Child Health. 2005; 41:265-8.
[38] Johnson DW, Dent $H$, Yao Q, et al. Frequencies of hepatitis $B$ and $C$ infections among haemodialysis and peritoneal dialysis patients in Asia-Pacific countries: analysis of registry data. Nephrol Dial Transplant. 2009; 24:1598-603.

[39] Wait S, Kell E, Hamid S, et al. Hepatitis B and hepatitis $C$ in southeast and southern Asia: challenges for governments. Lancet Gastroenterol Hepatol. 2016; 1:248-55.

[40] McDonald SA, Dahlui M, Mohamed R, et al. Projections of the current and future disease burden of hepatitis $C$ virus infection in Malaysia. PloS One. 2015; 10:e0128091.

[41] Mukherjee TI, Pillai V, Ali SH, et al. Evaluation of a hepatitis $\mathrm{C}$ education intervention with clients enrolled in methadone maintenance and needle/syringe programmes in Malaysia. Int J Drug Policy. 2017; 47:144-52.

[42] Lewallen S, Courtright P. Epidemiology in practice: case-control studies. Community Eye Health. 1998; 11:57-8. 